\title{
The association of polymorphisms in hormone metabolism pathway genes, menopausal hormone therapy, and breast cancer risk: a nested case-control study in the California Teachers Study cohort
}

Eunjung Lee ${ }^{1}$, Fredrick Schumacher ${ }^{1}$, Juan Pablo Lewinger ${ }^{1}$, Susan L Neuhausen ${ }^{2}$, Hoda Anton-Culver ${ }^{3}$, Pamela L Horn-Ross ${ }^{4}$, Katherine D Henderson ${ }^{2}$, Argyrios Ziogas ${ }^{3}$, David Van Den Berg ${ }^{1}$, Leslie Bernstein ${ }^{2}$ and Giske Ursin ${ }^{1,5,6^{*}}$

\begin{abstract}
Introduction: The female sex steroids estrogen and progesterone are important in breast cancer etiology. It therefore seems plausible that variation in genes involved in metabolism of these hormones may affect breast cancer risk, and that these associations may vary depending on menopausal status and use of hormone therapy.

Methods: We conducted a nested case-control study of breast cancer in the California Teachers Study cohort. We analyzed 317 tagging single nucleotide polymorphisms (SNPs) in 24 hormone pathway genes in 2746 non-Hispanic white women: 1351 cases and 1395 controls. Odds ratios (ORs) and 95\% confidence intervals (Cls) were estimated by fitting conditional logistic regression models using all women or subgroups of women defined by menopausal status and hormone therapy use. $P$ values were adjusted for multiple correlated tests $\left(P_{\text {ACT }}\right)$.

Results: The strongest associations were observed for SNPs in SLCO1B1, a solute carrier organic anion transporter gene, which transports estradiol-17/-glucuronide and estrone-3-sulfate from the blood into hepatocytes. Ten of 38 tagging SNPS of SLCO1B1 showed significant associations with postmenopausal breast cancer risk; 5 SNPs (rs1 1045777, rs11045773, rs16923519, rs4149057, rs11045884) remained statistically significant after adjusting for multiple testing within this gene $\left(P_{\mathrm{ACT}}=0.019-0.046\right)$. In postmenopausal women who were using combined estrogen-progestin therapy (EPT) at cohort enrollment, the OR of breast cancer was 2.31 ( $95 \% \mathrm{Cl}=1.47-3.62)$ per minor allele of rs4149013 in SLCO1B1 ( $P=0.0003$; within-gene $P_{\mathrm{ACT}}=0.002$; overall $\left.P_{\mathrm{ACT}}=0.023\right)$. SNPs in other hormone pathway genes evaluated in this study were not associated with breast cancer risk in premenopausal or postmenopausal women.
\end{abstract}

Conclusions: We found evidence that genetic variation in SLCO1B1 is associated with breast cancer risk in postmenopausal women, particularly among those using EPT.

\footnotetext{
* Correspondence: gursin@usc.edu

'Department of Preventive Medicine, Keck School of Medicine, University of

Southern California, 1441 Eastlake Avenue, Los Angeles, CA 90089, USA

Full list of author information is available at the end of the article
} 


\section{Introduction}

Reproductive and hormonal factors, including age at menarche, parity, number of full-term pregnancies, age at first full-term pregnancy, breastfeeding, age at menopause, body mass index (BMI), and physical activity, are associated with breast cancer risk [1,2]. Consistent with these observations, breast cancer risk is higher among women with higher circulating levels of endogenous estrogen [3-5] and among women using combined postmenopausal estrogen and progestin therapy (EPT) [6-11].

Sex steroid hormones, whether endogenous or exogenous, are synthesized and metabolized by many different enzymes (reviewed in [12]). Therefore, genetic variation among genes regulating sex steroid hormone levels may increase or decrease breast cancer risk by influencing hormone metabolism. Polymorphisms in several hormone pathway genes, including CYP19A1 and $C O M T$, have been associated with endogenous hormone levels [13-16]; however, studies investigating the association of genetic variation in hormone metabolism genes and breast cancer risk have generated mixed results [14,17-29]. Recently, a large study from the Breast and Prostate Cancer Cohort Consortium (BPC3) comprehensively analyzed 37 steroid hormone metabolism pathway genes in relation to breast cancer risk and reported null associations [16,30], suggesting that inconsistencies in the literature may be due to findings observed by chance in small studies. However, it is possible that the inconsistencies may be explained at least partly by differences in the distribution of environmental factors that modify the effects of genetic polymorphisms.

EPT use increases breast cancer risk to a much greater extent than estrogen-only therapy (ET) [6-11]. Therefore, it is important to examine EPT and ET use separately when investigating gene-hormone therapy $(\mathrm{HT})$ interactions. To date, few studies have investigated the gene-HT interactions by hormone formulation by using a comprehensive single-nucleotide polymorphism (SNP)-tagging approach. The California Teachers Study is an effective resource to study these questions because detailed data on hormone use were collected at baseline, and approximately $41 \%$ and $28 \%$ of the postmenopausal participants reported current use of EPT and ET, respectively [31]. Thus, using data from a case-control study nested within the California Teachers Study, we systematically investigated whether any of 24 hormone metabolism pathway genes or their interactions with HT were associated with breast cancer risk.

\section{Materials and methods Participants}

The California Teachers Study has been previously described in detail [32]. Briefly, the California Teachers
Study is a prospective cohort of women who were current, recent, or retired California public school professionals in 1995. By returning a baseline questionnaire in 1995-1996, 133,479 women joined the cohort and provided detailed information on menopausal status, HT use, and other lifestyle and medical factors. The baseline questionnaire is available on the California Teachers Study website [33]. Cancer diagnoses in the cohort are identified through annual linkage with the California Cancer Registry, which identifies at least $99 \%$ of cancers diagnosed in California [34]. The California Teachers Study has been approved by the institutional review boards at all participating institutions: the Cancer Prevention Institute of California (CPIC), the University of California at Irvine (UCI), the University of Southern California (USC), and the City of Hope in accordance with assurances filed with and approved by the US Department of Health and Human Services.

The nested breast cancer case-control study was designed to obtain biospecimens from breast cancer cases and unaffected controls within the 113,590 members of the cohort who were less than 80 years old at baseline, had continued residence in California during the study period (1995 to time of blood draw), and, before 1998, had no prior history of invasive or in situ breast cancer. Cases were women who had a histologically confirmed invasive primary carcinoma of the breast (International Classification of Disease for Oncology code C50 restricted to morphology codes under 8,590) and who were 80 years old or younger between 1 January 1998 and 31 May 2007. One control participant per case was randomly selected from the cohort and frequency-matched to the case on age at baseline (within 5-year age groups), self-reported race/ethnicity (white, African-American, Latina, Asian, and other), and three broad geographic regions (that is, California Teachers Study specimen collection centers). Cancer cases were identified through quarterly linkages of the cohort to the California Cancer Registry database. Control selection was conducted on a quarterly basis without replacement. For each wave of control selection, a reference date was determined (that is, January, April, July, and October of each year). Nearly equal numbers of controls were selected in each wave. One control participant had her breast cancer diagnosed after her control selection and was included in the analysis as both a control and a case.

\section{Collection of biological specimens and DNA extraction}

Collection of biological specimens was conducted at three study centers (CPIC in the northern half of California and USC and UCI in the southern half). Women who declined blood draw were asked whether they were 
willing to provide a saliva sample, and, if so, an Oragene DNA self-collection kit (DNA Genotek, Kanata, ON, Canada) was mailed to the participant with informed consent and return postage paid mailing materials. From the 8,118 eligible participants $(2,618$ cases and 5,500 selected controls), we collected biological specimens for $74 \%$ of the cases (1,923 cases: 1,684 blood specimens and 239 saliva specimens) and $61 \%$ of the controls (3,350 controls: 3,012 blood specimens and 338 saliva specimens). All biologic samples were sent via overnight courier to the UCI laboratory for DNA extraction. DNA was extracted from blood clots by using Qiagen Clotspin Baskets and DNA QIAmp DNA Blood maxi kits (Qiagen Inc., Valencia, CA, USA) in accordance with Qiagen protocols. DNA was extracted from saliva samples by using the Oragene protocol (DNA Genotek). The nested breast cancer case-control study of the California Teachers Study has been approved by the institutional review boards at all participating institutions, and all participants provided written informed consent.

\section{Tagging SNP selection and genotyping}

We investigated 24 genes that are involved in female sex steroid hormone biosynthesis, metabolism, or excretion. Reviews on the function of these genes are available elsewhere $[12,35,36]$. For 21 of these genes, a tagging SNP approach was used (Supplementary Table $\mathrm{S} 1$ in Additional file 1). For 16 of the 21 genes, we selected linkage disequilibrium tagging SNPs across each gene, $20 \mathrm{~kb}$ upstream of $5^{\prime}$ untranslated region (UTR) and $10 \mathrm{~kb}$ downstream of 3' UTR. The tagging SNPs were selected to capture all common SNPs (minor allele frequency (MAF) of at least 5\%) in individuals of European ancestry with minimum pairwise $R^{2}$ of at least 0.80 by using the Snagger software [37] and the data from the International HapMap Project for the white CEPH (Utah residents with ancestry from northern and western Europe) population (HapMap release 21, July 2006, genotype build 36 [38]). Tagging SNPs for five genes included in the present study had been selected by BPC3 by using the TagSNPs program $[30,39]$. To facilitate the comparison across studies, we used the BPC3-selected tagging SNPs for these five genes (Supplementary Table S1 in Additional file 1). The BPC3-selected tagging SNPs captured all common SNPs (MAF of at least 5\%) in whites with minimum pairwise $R^{2}$ of at least 0.8 . For the remaining 3 of the 24 genes, we genotyped a few selected SNPs due to space limitations of our genotyping platform. For CYP19A1, the selected SNPs were shown to be associated with circulating estrogen concentrations in a comprehensive analysis [13] (Supplementary Table S1 in Additional file 1).
A total of 1,751 breast cancer cases and 1,697 controls were available for genotyping. We included a random sample of 193 replicates (105 cases and 88 controls) to monitor reproducibility and track plate flips or switches. The DNA samples were genotyped for the selected tagging SNPs by using the Illumina Golden Gate Assay (Illumina, Inc., San Diego, CA, USA) in the USC Core Facility. About $10 \%$ of the genotyped samples, including 189 cases and 150 controls, had a genotyping success rate (call rate) of less than $90 \%$ and were excluded from the analyses. The genotyping concordance rate based on the 160 duplicate samples with a call rate of at least $90 \%$ was $99.9 \%$. Call rates were lower when the DNA was obtained from saliva samples: $23 \%$ of saliva samples and $8 \%$ of blood samples had a call rate of less than $90 \%$ and these samples therefore were excluded from the analyses. However, the genotyping concordance after excluding the low call rate samples was excellent for saliva samples (greater than 99.9\%). In addition, results from sensitivity analyses excluding saliva samples were similar to those using all samples. For the present study, we also excluded 88 women (52 cases and 36 controls) who self-reported to have had a previous history of cancer, leaving 1,510 cases and 1,511 controls. Because the majority (approximately 91\%) of participants were nonHispanic whites, we restricted the analyses to 2,746 non-Hispanic white women (1,351 cases and 1,395 controls).

Of the 355 SNPs genotyped, 332 had an SNP call rate of at least $90 \%$. We excluded an additional three SNPs that had discordant readings in more than two duplicate pairs, eight SNPs with an MAF of less than 1\% among non-Hispanic white controls, and four SNPs in COMT, CYP11A, SULT1A1; SULT1A2, UGT1A8 not in HardyWeinberg equilibrium $(P<0.001)$; thus, we analyzed 317 SNPs in the present study.

For 19 of the 20 genes for which we used the tagging SNP approach, the genotyped tagging SNPs efficiently captured $70 \%$ to $100 \%$ of all common SNPs (MAF of greater than 5\%) in the HapMap dataset of European ancestry (HapMap release 24, genotype build 36) with pairwise $\mathrm{R}^{2}$ of at least 0.80 (Supplementary Table $\mathrm{S} 1$ in Additional file 1). We did not have sufficient tagging coverage for CYP21A2.

\section{Imputation}

We imputed SNPs in gene regions where we found a statistically significant association $(P<0.01$ before multiple testing correction) with breast cancer risk among all women or among subgroups defined by menopausal status. To do this, we used publicly available HapMap genotype data in the CEPH population as the reference sample (HapMap release 24, genotype build 36 [38]) and MACH 1.0 [40]. We excluded imputed SNPs when the 
MAF was less than $1 \%$ or when the $R^{2}$ was less than $0.30[40]$.

\section{Statistical analyses}

We used conditional logistic regression models with strata defined by 5 -year age group and the three specimen collection centers to estimate the odds ratios (ORs), 95\% confidence intervals (CIs), and $P$ values associated with each SNP by using log-additive models. The results did not change after further adjustment for potential confounders including menopausal status (premenopausal, postmenopausal, and unknown), HT use status at baseline (never used HT, currently using ET, currently using EPT, used HT in the past, and unknown), BMI (less than 25, 25 to less than 30, at least $30 \mathrm{~kg} / \mathrm{m}^{2}$, and unknown), parity (0, 1 to 2 , at least 3 , and unknown), and oral contraceptive use (never, ever, and unknown). Therefore, we presented the results from the conditional logistic regression models not adjusting for these potential confounders.

We performed subgroup-specific analyses by menopausal status and, among postmenopausal women, by HT use at baseline, defining the groups of interest as never used HT, currently using ET, and currently using EPT. We calculated $P$ for interaction by likelihood ratio test comparing the model with and without the product term of genotype $(0,1$, and 2 copies of minor allele, as ordinal variable) and menopausal status or HT use. The interaction tests for HT use were done separately for current EPT use (as compared with never HT use) and for current ET use (as compared with never HT use).

\section{Results}

A greater proportion of breast cancer cases than controls were currently using EPT at baseline; a lower proportion of cases than controls had high parity. Cases also had slightly earlier age at menarche than control women (Table 1).

Evaluation of the q-q plot of the $P$ values for the association between the 317 SNPs in the 24 hormone metabolism genes and breast cancer risk showed no evidence of systematic bias (Supplementary Figure S1 in Additional file 2).

We observed statistically significant associations at a $P$ value of less than 0.01 with two SNPs in SLCO1B1 and one SNP in HSD17B4 in the overall analysis (Table 2). However, after multiple comparisons were corrected for, none of these associations was statistically significant. For postmenopausal women, 10 SNPs in $S L C O 1 B 1$ were associated with breast cancer risk with an uncorrected $P$ value of less than 0.01 . Of these, the associations for SNPs rs11045773, rs11045777, rs16923519, rs4149057, and rs11045884 remained statistically significant after correction for multiple testing within the gene (within-gene $\mathrm{P}_{\mathrm{ACT}}<$ 0.05). However, after multiple testing across all genes was corrected for, none of these associations was statistically significant. The ORs and 95\% CIs associated for all tested SNPs are provided in Supplementary Table S2 in Additional file 3. There was some evidence that, of these, rs4149013 in SLCO1B1 was associated with breast cancer risk in postmenopausal women (OR 1.39 , 95\% CI 1.07 to 1.81 ; uncorrected $P=0.015$ ).

When examining by $\mathrm{HT}$ use, we observed a strong association between several SNPs in SLCO1B1 and postmenopausal breast cancer risk in current EPT users (Table 3). Breast cancer risk among postmenopausal women who were using EPT at baseline increased more than twofold per minor allele of rs4149013 (OR 2.31, $95 \% \mathrm{CI} 1.47$ to $3.62 ; P=0.0003$, within-gene $\mathrm{P}_{\mathrm{ACT}}=$ $0.002)$. This association was statistically significant even after $\mathrm{P}_{\mathrm{ACT}}$ adjustment across all SNPs studied $\left(\mathrm{P}_{\mathrm{ACT}}=\right.$ 0.023 ). The $P$ value for interaction (EPT versus never HT use) was 0.019 (not corrected for multiple testing). When we combined the homozygous and heterozygous minor allele carriers (that is, a dominant genetic model), we observed similar OR estimates and $P$ values (OR 2.43, 95\% CI 1.53 to $3.85 ; P=0.0002$ ) (Supplementary Table S3 in Additional file 4). We did not observe any significant associations in never HT users and ET users. There was no statistically significant difference in effects when stratifying by estrogen receptor status.

\section{Discussion}

In this case-control study nested within the California Teachers Study cohort, genetic variation in only 1 (SLCO1B1) of 24 genes in the hormone metabolism pathway genes was associated with breast cancer risk. SLCO1B1, a gene involved in the hepatic uptake of female sex steroids, seemed to be associated with breast cancer risk among postmenopausal women. This association was statistically significant after correcting for multiple testing within the gene but was not statistically significant after we corrected for multiple testing across genes. However, there was also an indication that EPT may interact with SNPs in SLCO1B1; one variant in SLCO1B1 (rs4149013) was statistically significantly associated with breast cancer risk in EPT users.

Our findings of no association between SNPs in hormone metabolism pathway genes and breast cancer risk are consistent with the results from other large studies such as BPC3 [13,29,30,41] and meta-analyses of selected functional SNPs in CYP1A1 [23], SULT1A1 [42,43], CYP1B1 [44,45], and COMT [46], although two smaller meta-analyses of selected functional SNP in COMT supported an association in Caucasian populations $[47,48]$. Although a few studies have suggested associations between genetic polymorphisms in other 
Table 1 Characteristics of the study participants at time of joining the cohort

\begin{tabular}{|c|c|c|c|c|}
\hline \multirow[b]{2}{*}{ Characteristics } & \multicolumn{2}{|c|}{ Control } & \multicolumn{2}{|c|}{ Case } \\
\hline & Number & Percentage & Number & Percentage \\
\hline Number & 1,395 & & 1,351 & \\
\hline Mean age $\pm S D$, years & $56.1 \pm 9.5$ & & $55.0 \pm 9.4$ & \\
\hline \multicolumn{5}{|l|}{ Menopausal status } \\
\hline Premenopausal & 347 & 25.3 & 364 & 27.5 \\
\hline Postmenopausal $^{a}$ & 1,024 & 74.7 & 962 & 72.5 \\
\hline Unknown & 24 & - & 25 & - \\
\hline \multicolumn{5}{|l|}{ HT use among postmenopausal women } \\
\hline Never used HT & 153 & 15.8 & 112 & 12.4 \\
\hline Current ET use & 277 & 28.7 & 230 & 25.5 \\
\hline Current EPT use & 401 & 41.5 & 468 & 51.9 \\
\hline Former ET or EPT use & 122 & 12.6 & 80 & 8.9 \\
\hline Ever used progestin alone & 13 & 1.3 & 12 & 1.3 \\
\hline Unknown & 58 & - & 60 & - \\
\hline \multicolumn{5}{|l|}{ Parity/total number of FTPs } \\
\hline Nulligravid & 221 & 16.1 & 219 & 16.4 \\
\hline Gravid, nulliparous & 61 & 4.4 & 66 & 4.9 \\
\hline 1 FTP & 159 & 11.6 & 174 & 13.0 \\
\hline 2 FTPs & 487 & 35.4 & 472 & 35.3 \\
\hline 3 FTPS & 274 & 20.0 & 277 & 20.7 \\
\hline 4+ FTPs & 172 & 12.5 & 128 & 9.6 \\
\hline Unknown & 21 & - & 15 & - \\
\hline \multicolumn{5}{|l|}{ Body mass index } \\
\hline$<25 \mathrm{~kg} / \mathrm{m}^{2}$ & 765 & 54.8 & 778 & 58.9 \\
\hline 25 to $<30 \mathrm{~kg} / \mathrm{m}^{2}$ & 387 & 27.7 & 384 & 29.1 \\
\hline $30+\mathrm{kg} / \mathrm{m}^{2}$ & 195 & 14.0 & 159 & 12.0 \\
\hline Unknown & 48 & - & 30 & - \\
\hline \multicolumn{5}{|l|}{ Age at menarche } \\
\hline$\leq 10$ years & 100 & 7.3 & 100 & 7.5 \\
\hline $11-12$ years & 600 & 43.6 & 599 & 44.8 \\
\hline $13-14$ years & 565 & 41.0 & 542 & 40.6 \\
\hline $15-16$ years & 102 & 7.4 & 82 & 6.1 \\
\hline $17+$ years & 10 & 0.7 & 13 & 1.0 \\
\hline Unknown/Never had menarche & 18 & - & 15 & - \\
\hline \multicolumn{5}{|c|}{ Family history of breast cancer (first-degree relative) } \\
\hline No & 1,167 & 86.1 & 1,085 & 82.1 \\
\hline Yes & 189 & 13.9 & 236 & 17.9 \\
\hline Unknown & 39 & - & 30 & - \\
\hline \multicolumn{5}{|l|}{ History of breast biopsy } \\
\hline No & 1,086 & 77.8 & 1,034 & 76.5 \\
\hline Yes & 309 & 22.2 & 317 & 23.5 \\
\hline \multicolumn{5}{|c|}{ Screening mammograms within last 2 years } \\
\hline No & 138 & 10.0 & 146 & 10.9 \\
\hline Yes & 1,241 & 90.0 & 1,193 & 89.1 \\
\hline Unknown & 16 & - & 12 & - \\
\hline
\end{tabular}

${ }^{a}$ Includes perimenopausal women. EPT, estrogen progestin combined therapy; ET, estrogen therapy; FTP, full-term pregnancy; HT, hormone therapy; SD, standard deviation. 


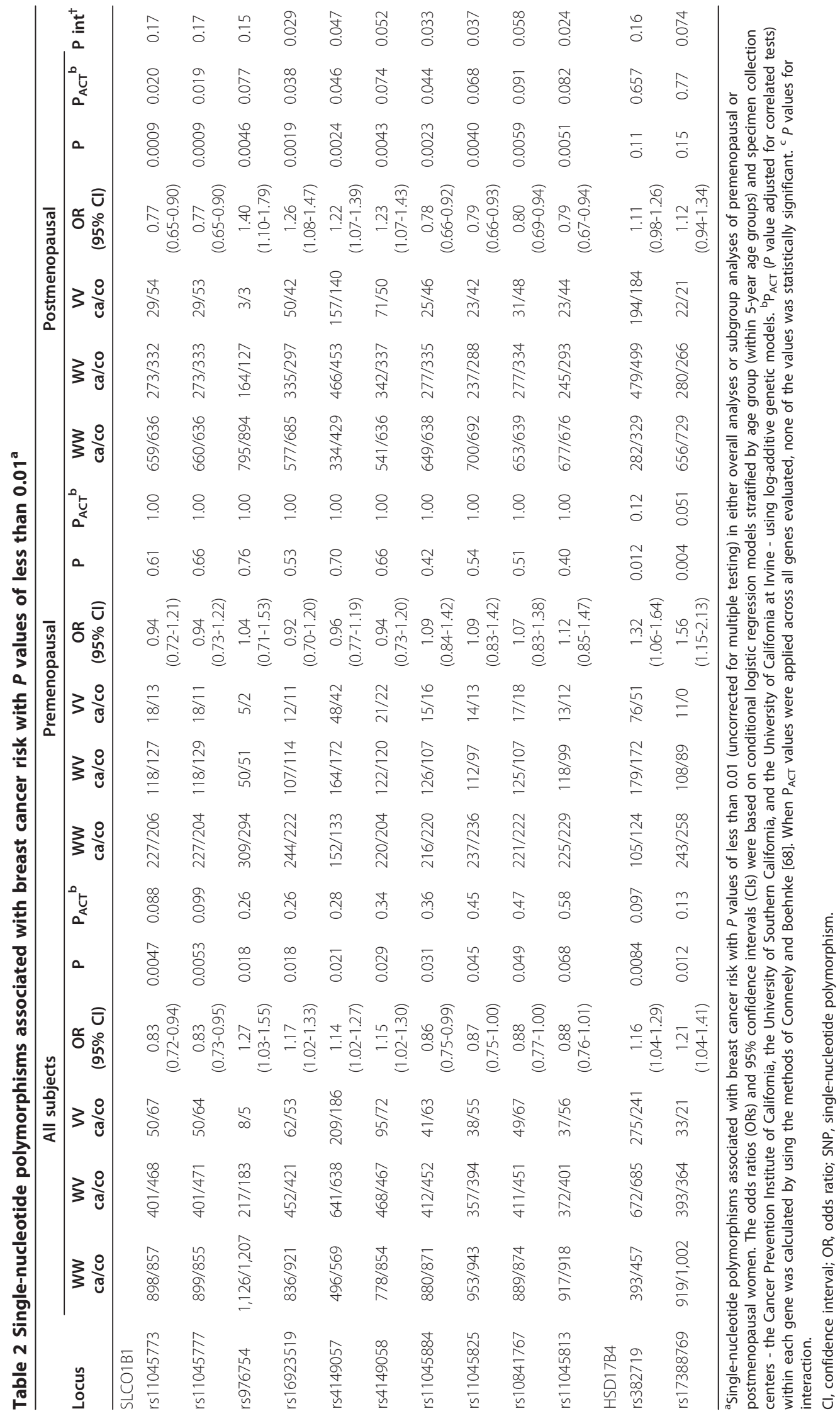




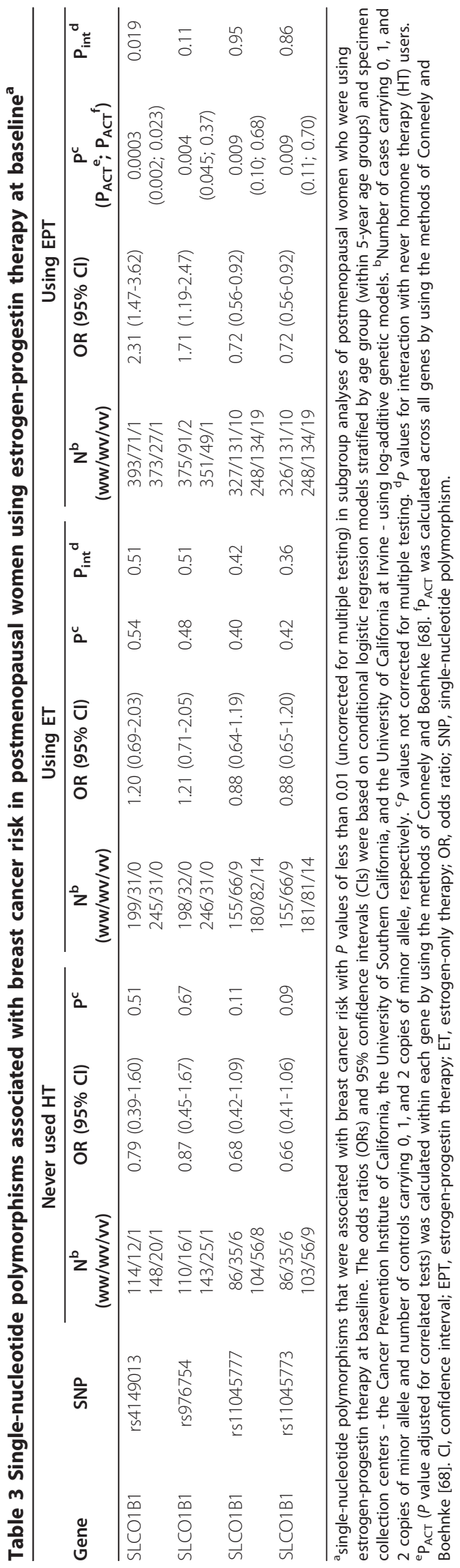


hormone pathway genes, including $C Y P 11 A[25,26]$, CYP1A1/CYP1A2 [49,50], CYP1B1 [51,52], SULT1E1 [53], or COMT [54], many of these associations were not observed consistently [30,49,50,55-57]. In addition, the few studies other than BPC3 that have investigated polymorphisms in CYP2C9 [51], CYP3A4 [49,51,56], HSD17B2 [58], SRD5A1 [56], and UGT2B7 [51], in relation to breast cancer risk among Caucasian populations, have reported no associations. However, a recent study using admixture maximum likelihood (AML)-based global tests reported that genetic variation in androgenestrogen conversion pathway was associated with breast cancer risk, although no single SNP was significant after correcting multiple testing [59].

To our knowledge, no studies have investigated genetic variation in $S L C O 1 B 1$ and breast cancer risk by hormone therapy use. $S L C O 1 B 1$, also known as $O A T P$ $C$ or $S L C 21 A 6$, is expressed in the liver and plays an important role in transporting drugs and endogenous substrates from the blood into the hepatocytes (reviewed in [60]). Endogenous substrates of SLCO1B1 include steroid hormone conjugates such as estradiol-17 $\beta$-glucuronide and estrone-3-sulfate $[61,62]$. Serum estrone sulfate (E1S) is a major form of circulating estrogen in postmenopausal women and can be converted to estradiol in breast tissue [63]. E1S is also a major component of conjugated equine estrogens, the estrogen component of the predominant (prior to 2002) HT regimens in the US [64]. Genetic variation in SLCO1B1 has been shown to decrease the uptake of E1S and estradiol glucuronide in several $[61,65]$ but not all [66] studies. Furthermore, one study has shown that genetic variation in $S L C O 1 B 1$ is associated with blood E1S levels in Caucasians [61], suggesting that genetic variation in SLCO1B1 may interact with HT use. Rs4149013 is located near the 5' end of $S L C O 1 B 1$. The functional significance of this variant is not known, but even if there is none, this variant could be linked to a causal allele.

In the publicly available Cancer Genetic Markers of Susceptibility (CGEMS) breast cancer data [67], we found additional support implicating SLCO1B1. In CGEMS, five genotyped SNPs in SLCO1B1 (rs704166, rs852550, rs852549, rs7489119, and rs2306283) were associated with breast cancer risk with a $P$ value of less than 0.05. These 5 SNPs, as imputed genotypes, were null in our dataset (data not shown), but this could be due to misclassification from imputation or false-positive associations across both CGEMS and our data. However, our findings and those of CGEMS, combined with the previous literature on the role of this gene in affecting estrone absorption, suggest that further investigation of the role of SLCO1B1 genetic variation and its interaction with EPT on breast cancer risk is warranted.
The strengths of this study include the systematic investigation of a large number of hormone metabolism genes and the detailed information on HT use collected at baseline. A limitation of our study was the inability to genotype all tagging SNPs for several of the genes of interest, including AKR1C4, ARSC, and CYP19A1. Thus, we cannot exclude the possibility that the lack of associations for these loci was due to incomplete tagging. Overall, we had $80 \%$ statistical power to detect ORs ranging from 1.17 to 1.40 for SNPs with an MAF of 0.05 to 0.49 by using log-additive models and an alpha of 0.05 . For the subset analyses among postmenopausal women, the minimum detectable OR ranged from 1.20 to 1.46 for SNPs with an MAF of at least 0.05. The statistical power to detect associations in premenopausal women or to detect interactions with menopausal status or HT use was limited. Another limitation of this study is that HT use status assessed at baseline may have changed during follow-up. The participation rates (donating biological specimens for this nested case-control study) among the potentially eligible cohort members were moderate $(74 \%$ for cases and $61 \%$ for controls). However, it is unlikely that the participation was differential according to genotype and case status, and thus selection bias is unlikely to have influenced our findings.

\section{Conclusions}

Common genetic variations in SLCO1B1 may be associated with breast cancer risk in postmenopausal women, particularly in EPT users. The known effects of variants in $S L C O 1 B 1$ on estrogen metabolism suggest that further study of the role of SLCO1B1 is warranted.

\section{Additional material}

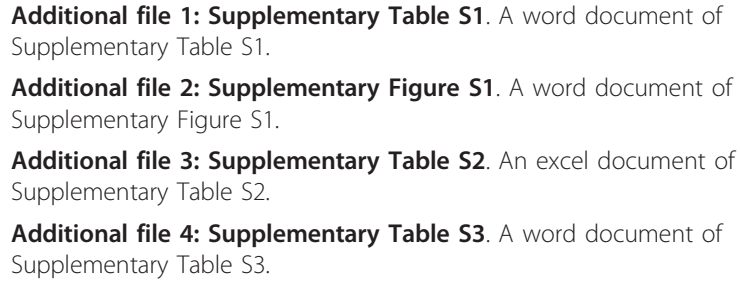

Additional file 3: Supplementary Table S2. An excel document of Supplementary Table S2.

Additional file 4: Supplementary Table S3. A word document of Supplementary Table S3.

\section{Abbreviations}

BMI: body mass index; BPC3: Breast and Prostate Cancer Cohort Consortium; CEPH: Utah residents with ancestry from northern and western Europe: CGEMS: Cancer Genetic Markers of Susceptibility; Cl: confidence interval; CPIC: Cancer Prevention Institute of California; E1S: estrone sulfate; EPT: estrogen progestin combined therapy; ET: estrogen therapy; HT: hormone therapy; MAF: minor allele frequency; OR: odds ratio; $P_{\text {ACT: }} P$ value adjusted for multiple correlated tests; SNP: single-nucleotide polymorphism; UCI: University of California at Irvine; USC: University of Southern California; UTR: untranslated region. 


\section{Acknowledgements}

This research was supported by grants R01 CA77398, CA17054, and K05 CA 136967 from the National Cancer Institute and contract 97-10500 from the California Breast Cancer Research Fund. EL was supported by California Breast Cancer Research Program 14FB-0104. The funding sources did not contribute to the design or conduct of the study or to the writing or submission of the manuscript.

The collection of cancer incidence data used in this study was supported by the California Department of Health Services as part of the statewide cancer reporting program mandated by California Health and Safety Code Section 103885; the National Cancer Institute's Surveillance, Epidemiology and End Results Program under contract N01-PC-35136 awarded to the Cancer Prevention Institute of California (formerly the Northern California Cancer Center), contract N01-PC-35139 awarded to the University of Southern California, and contract N02-PC-15105 awarded to the Public Health Institute; and the Centers for Disease Control and Prevention's National Program of Cancer Registries under agreement \#U55/CCR921930-02 awarded to the Public Health Institute. The ideas and opinions expressed herein are those of the authors, and endorsement by the California Health and Human Services Agency, the National Cancer Institute, or the Centers for Disease Control and Prevention or their contractors and subcontractors is not intended, nor should it be inferred.

The authors would like to thank the members of the California Teachers Study Steering Committee who are responsible for the formation and maintenance of the cohort within which this study was conducted but who did not directly contribute to the present article: Ellen T Chang, Christina A Clarke, Dennis Deapen, James V Lacey Jr., Huiyan Ma, David O Nelson, Rich Pinder, Peggy Reynolds, Daniel O Stram, Dee W West, and Sophia S Wang.

\section{Author details}

'Department of Preventive Medicine, Keck School of Medicine, University of Southern California, 1441 Eastlake Avenue, Los Angeles, CA 90089, USA. ${ }^{2}$ Department of Population Sciences, Beckman Research Institute, City of Hope, 1500 Duarte Road, Duarte, CA 91010, USA. ${ }^{3}$ Department of Epidemiology, School of Medicine, University of California, 224 Irvine Hall, Irvine, CA 92697-7550, USA. ${ }^{4}$ Cancer Prevention Institute of California, 2201 Walnut Avenue, Fremont, CA 94538, USA. ${ }^{5}$ Department of Nutrition, University of Oslo, Sognsvannsveien 9, 0372 Oslo, Norway. ${ }^{6}$ Cancer Registry of Norway, PB 5313, Majorstuen, 0304 Oslo, Norway.

\section{Authors' contributions}

EL performed the statistical analysis and drafted the manuscript. FS, JPL, and $S L N$ participated in the statistical analysis and drafted the manuscript. PLH-R, $H A C$, and LB participated in the design of the nested case-control study, were responsible for specimen collection, and obtained grant funding for the study. KDH prepared analytic variables, including menopausal status and hormone therapy use. AZ participated in coordinating the specimen process and SNP selection. DVDB coordinated tagging SNP selection and performed the genotyping. GU participated in the design of the study and in SNP selection and supervised the analysis and manuscript preparation. All authors edited the manuscript and provided comments on the intellectual content and read and approved the final manuscript.

\section{Competing interests}

The authors declare that they have no competing interests.

Received: 9 December 2010 Revised: 15 March 2011

Accepted: 1 April 2011 Published: 1 April 2011

\section{References}

1. Collaborative Group on Hormonal Factors in Breast Cancer: Breast cancer and breastfeeding: collaborative reanalysis of individual data from 47 epidemiological studies in 30 countries, including 50302 women with breast cancer and 96973 women without the disease. Lancet 2002, 360:187-195

2. Kelsey JL, Gammon MD, John EM: Reproductive factors and breast cancer. Epidemiol Rev 1993, 15:36-47.

3. Key T, Appleby P, Barnes I, Reeves G: Endogenous sex hormones and breast cancer in postmenopausal women: reanalysis of nine prospective studies. J Natl Cancer Inst 2002, 94:606-616.
4. Tworoger SS, Missmer SA, Barbieri RL, Willett WC, Colditz GA, Hankinson SE: Plasma sex hormone concentrations and subsequent risk of breast cancer among women using postmenopausal hormones. J Natl Cancer Inst 2005, 97:595-602.

5. Eliassen AH, Missmer SA, Tworoger SS, Spiegelman D, Barbieri RL, Dowsett M, Hankinson SE: Endogenous steroid hormone concentrations and risk of breast cancer among premenopausal women. J Natl Cancer Inst 2006, 98:1406-1415.

6. Breast cancer and hormone replacement therapy: collaborative reanalysis of data from 51 epidemiological studies of 52,705 women with breast cancer and 108,411 women without breast cancer: Collaborative Group on Hormonal Factors in Breast Cancer. Lancet 1997, 350:1047-1059.

7. Ross RK, Paganini-Hill A, Wan PC, Pike MC: Effect of hormone replacement therapy on breast cancer risk: estrogen versus estrogen plus progestin. $J$ Natl Cancer Inst 2000, 92:328-332.

8. Schairer C, Lubin J, Troisi R, Sturgeon S, Brinton L, Hoover R: Menopausal estrogen and estrogen-progestin replacement therapy and breast cancer risk. JAMA 2000, 283:485-491.

9. Olsson HL, Ingvar C, Bladstrom A: Hormone replacement therapy containing progestins and given continuously increases breast carcinoma risk in Sweden. Cancer 2003, 97:1387-1392.

10. Farquhar CM, Marjoribanks J, Lethaby A, Lamberts Q, Suckling JA: Long term hormone therapy for perimenopausal and postmenopausal women. Cochrane Database Syst Rev 2005, 3:CD004143.

11. Rossouw JE, Anderson GL, Prentice RL, LaCroix AZ, Kooperberg C, Stefanick ML, Jackson RD, Beresford SA, Howard BV, Johnson KC, Kotchen JM, Ockene J: Risks and benefits of estrogen plus progestin in healthy postmenopausal women: principal results from the Women's Health Initiative randomized controlled trial. JAMA 2002, 288:321-333.

12. Zhu BT, Conney AH: Functional role of estrogen metabolism in target cells: review and perspectives. Carcinogenesis 1998, 19:1-27.

13. Haiman CA, Dossus L, Setiawan WW, Stram DO, Dunning AM, Thomas G, Thun MJ, Albanes D, Altshuler D, Ardanaz E, Boeing H, Buring J, Burtt N, Calle EE, Chanock S, Clavel-Chapelon F, Colditz GA, Cox DG, Feigelson HS, Hankinson SE, Hayes RB, Henderson BE, Hirschhorn JN, Hoover R, Hunter DJ, Kaaks R, Kolonel LN, Le Marchand L, Lenner P, Lund E, et al: Genetic variation at the CYP19A1 locus predicts circulating estrogen levels but not breast cancer risk in postmenopausal women. Cancer Res 2007, 67:1893-1897.

14. Dunning AM, Dowsett M, Healey CS, Tee L, Luben RN, Folkerd E, Novik KL, Kelemen L, Ogata S, Pharoah PD, Easton DF, Day NE, Ponder BA: Polymorphisms associated with circulating sex hormone levels in postmenopausal women. I Natl Cancer Inst 2004, 96:936-945.

15. Tworoger SS, Chubak J, Aiello EJ, Ulrich CM, Atkinson C, Potter JD, Yasui Y Stapleton PL, Lampe JW, Farin FM, Stanczyk FZ, McTiernan A: Association of CYP17, CYP19, CYP1B1, and COMT polymorphisms with serum and urinary sex hormone concentrations in postmenopausal women. Cancer Epidemiol Biomarkers Prev 2004, 13:94-101.

16. Beckmann L, Husing A, Setiawan WW, Amiano P, Clavel-Chapelon F, Chanock SJ, Cox DG, Diver R, Dossus L, Feigelson HS, Haiman C, Hallmans G, Hayes RB, Henderson BE, Hoover RN, Hunter DJ, Khaw K, Kolonel LN, Kraft P, Lund E, Le Marchand L, Peeters PH, Riboli E, Stram D, Thomas G, Thun MJ, Tumino R, Trichopoulos D, Vogel U, Willett WC, et al: Comprehensive analysis of hormone and genetic variation in 36 genes related to steroid hormone metabolism in pre- and postmenopausal women from the breast and prostate cancer cohort consortium (BPC3). $J$ Clin Endocrinol Metab 2011, 96:E360-367.

17. Dunning AM, Healey CS, Pharoah PD, Teare MD, Ponder BA, Easton DF: A systematic review of genetic polymorphisms and breast cancer risk. Cancer Epidemiol Biomarkers Prev 1999, 8:843-854.

18. Haiman CA, Hankinson SE, Spiegelman D, Brown M, Hunter DJ: No association between a single nucleotide polymorphism in CYP19 and breast cancer risk. Cancer Epidemiol Biomarkers Prev 2002, 11:215-216.

19. Haiman CA, Hankinson SE, Spiegelman D, Colditz GA, Willett WC, Speizer FE, Kelsey KT, Hunter DJ: The relationship between a polymorphism in CYP17 with plasma hormone levels and breast cancer. Cancer Res 1999, 59:1015-1020.

20. Becchis M, Frairia R, Ferrera P, Fazzari A, Ondei S, Alfarano A, Coluccia C, Biglia N, Sismondi P, Fortunati N: The additionally glycosylated variant of human sex hormone-binding globulin (SHBG) is linked to estrogendependence of breast cancer. Breast Cancer Res Treat 1999, 54:101-107. 
21. Forsti A, Jin Q, Grzybowska E, Soderberg M, Zientek H, Sieminska M, Rogozinska-Szczepka J, Chmielik E, Utracka-Hutka B, Hemminki K: Sex hormone-binding globulin polymorphisms in familial and sporadic breast cancer. Carcinogenesis 2002, 23:1315-1320.

22. Low YL, Dunning AM, Dowsett M, Luben RN, Khaw KT, Wareham NJ, Bingham SA: Implications of gene-environment interaction in studies of gene variants in breast cancer: an example of dietary isoflavones and the D356N polymorphism in the sex hormone-binding globulin gene. Cancer Res 2006, 66:8980-8983.

23. Masson LF, Sharp L, Cotton SC, Little J: Cytochrome P-450 1A1 gene polymorphisms and risk of breast cancer: a HuGE review. Am J Epidemiol 2005, 161:901-915

24. Haiman CA, Stram DO, Pike MC, Kolonel LN, Burtt NP, Altshuler D, Hirschhorn J, Henderson BE: A comprehensive haplotype analysis of CYP19 and breast cancer risk: the Multiethnic Cohort. Hum Mol Genet 2003, 12:2679-2692.

25. Setiawan W, Cheng I, Stram DO, Giorgi E, Pike MC, Van Den Berg D, Pooler L, Burtt NP, Le Marchand L, Altshuler D, Hirschhorn J, Henderson BE, Haiman CA: A systematic assessment of common genetic variation in CYP11A and risk of breast cancer. Cancer Res 2006, 66:12019-12025.

26. Zheng W, Gao YT, Shu XO, Wen W, Cai Q, Dai Q, Smith JR: Populationbased case-control study of CYP11A gene polymorphism and breast cancer risk. Cancer Epidemiol Biomarkers Prev 2004, 13:709-714.

27. Kristensen VN, Borresen-Dale AL: Molecular epidemiology of breast cancer: genetic variation in steroid hormone metabolism. Mutat Res 2000, 462:323-333

28. Pharoah PD, Tyrer J, Dunning AM, Easton DF, Ponder BA: Association between common variation in 120 candidate genes and breast cancer risk. PLoS Genet 2007, 3:e42.

29. Feigelson HS, Cox DG, Cann HM, Wacholder S, Kaaks R, Henderson BE, Albanes D, Altshuler D, Berglund G, Berrino F, Bingham S, Buring JE, Burtt NP, Calle EE, Chanock SJ, Clavel-Chapelon F, Colditz G, Diver WR, Freedman ML, Haiman CA, Hankinson SE, Hayes RB, Hirschhorn JN, Hunter D, Kolonel LN, Kraft P, LeMarchand L, Linseisen J, Modi W, Navarro C, et al: Haplotype analysis of the HSD17B1 gene and risk of breast cancer: a comprehensive approach to multicenter analyses of prospective cohort studies. Cancer Res 2006, 66:2468-2475.

30. Canzian F, Cox DG, Setiawan WW, Stram DO, Ziegler RG, Dossus L, Beckmann L, Blanche H, Barricarte A, Berg CD, Bingham S, Buring J, Buys SS Calle EE, Chanock SJ, Clavel-Chapelon F, Delancey JO, Diver WR, Dorronsoro M, Haiman CA, Hallmans G, Hankinson SE, Hunter DJ, Husing A, Isaacs C, Khaw KT, Kolonel LN, Kraft P, Le Marchand L, Lund E, et al: Comprehensive analysis of common genetic variation in 61 genes related to steroid hormone and insulin-like growth factor-I metabolism and breast cancer risk in the $\mathrm{NCl}$ breast and prostate cancer cohort consortium. Hum Mol Genet 2010, 19:3873-3884.

31. Saxena $T$, Lee $E$, Henderson KD, Clarke CA, West D, Marshall SF, Deapen D, Bernstein L, Ursin G: Menopausal hormone therapy and subsequent risk of specific invasive breast cancer subtypes in the California Teachers Study. Cancer Epidemiol Biomarkers Prev 2010, 19:2366-2378.

32. Bernstein $L$, Allen $M$, Anton-Culver $H$, Deapen $D$, Horn-Ross $P L$, Peel $D$, Pinder R, Reynolds P, Sullivan-Halley J, West D, Wright W, Ziogas A, Ross RK: High breast cancer incidence rates among California teachers: results from the California Teachers Study (United States). Cancer Causes Control 2002, 13:625-635.

33. California Teachers Study homepage. [http://calteachersstudy.org/]

34. Kwong S, Perkin C, Morris C, Cohen R, Allen M, Wright W: Cancer in California: 1988-1999 Sacramento, CA: California Department of Health Services, Cancer Surveillance Section; 2001.

35. Li J, Eriksson L, Humphreys K, Czene K, Liu J, Tamimi RM, Lindström S, Hunter DJ, Vachon CM, Couch FJ, Scott CG, Lagiou P, Hall P: Genetic variation in the estrogen metabolic pathway and mammographic density as an intermediate phenotype of breast cancer. Breast Cancer Res 2010, 12:R19.

36. Payne $\mathrm{AH}$, Hales DB: Overview of steroidogenic enzymes in the pathway from cholesterol to active steroid hormones. Endocr Rev 2004, 25:947-970.

37. Edlund CK, Lee WH, Li D, Van Den Berg DJ, Conti DV: Snagger: a userfriendly program for incorporating additional information for tagSNP selection. BMC Bioinformatics 2008, 9:174.

38. International HapMap Project homepage. [http://hapmap.ncbi.n/m.nih. gov].
39. Stram DO, Haiman CA, Hirschhorn JN, Altshuler D, Kolonel LN, Henderson BE, Pike MC: Choosing haplotype-tagging SNPS based on unphased genotype data using a preliminary sample of unrelated subjects with an example from the Multiethnic Cohort Study. Hum Hered 2003, 55:27-36.

40. Li Y, Abecasis GR: Mach 1.0: Rapid Haplotype Reconstruction and Missing Genotype Inference. Am J Hum Genet 2006, S79:2290.

41. Setiawan W, Schumacher FR, Haiman CA, Stram DO, Albanes D, Altshuler D, Berglund G, Buring J, Calle EE, Clavel-Chapelon F, Cox DG, Gaziano JM, Hankinson SE, Hayes RB, Henderson BE, Hirschhorn J, Hoover R, Hunter DJ, Kaaks R, Kolonel LN, Kraft P, Ma J, Le Marchand L, Linseisen J, Lund E, Navarro C, Overvad K, Palli D, Peeters PH, Pike MC, et al: CYP17 genetic variation and risk of breast and prostate cancer from the National Cancer Institute Breast and Prostate Cancer Cohort Consortium (BPC3). Cancer Epidemiol Biomarkers Prev 2007, 16:2237-2246.

42. Sun Y, Zang Z, Xu X, Zhang Z, Zhong L, Zan W, Zhao Y, Sun L: The association of SULT1A1 codon 213 polymorphism and breast cancer susceptibility: meta-analysis from 16 studies involving 23,445 subjects. Breast Cancer Res Treat 2011, 125:215-219.

43. Wang Z, Fu Y, Tang C, Lu S, Chu WM: SULT1A1 R213H polymorphism and breast cancer risk: a meta-analysis based on 8,454 cases and 11,800 controls. Breast Cancer Res Treat 2010, 122:193-198.

44. Economopoulos KP, Sergentanis TN: Three polymorphisms in cytochrome P450 1B1 (CYP1B1) gene and breast cancer risk: a meta-analysis. Breast Cancer Res Treat 2010, 122:545-551.

45. Yao L, Fang F, Wu Q, Zhong Y, Yu L: No association between CYP1B1 Val432Leu polymorphism and breast cancer risk: a meta-analysis involving 40,303 subjects. Breast Cancer Res Treat 2010, 122:237-242.

46. Mao C, Wang XW, Qiu LX, Liao RY, Ding H, Chen Q: Lack of association between catechol-O-methyltransferase Val108/158Met polymorphism and breast cancer risk: a meta-analysis of 25,627 cases and 34,222 controls. Breast Cancer Res Treat 2010, 121:719-725.

47. Onay UV, Aaltonen K, Briollais L, Knight JA, Pabalan N, Kilpivaara O, Andrulis IL, Blomqvist C, Nevanlinna H, Ozcelik H: Combined effect of CCND1 and COMT polymorphisms and increased breast cancer risk. BMC Cancer 2008, 8:6.

48. Ding H, Fu Y, Chen W, Wang Z: COMT Val158Met polymorphism and breast cancer risk: evidence from 26 case-control studies. Breast Cancer Res Treat 2010, 123:265-270.

49. Le Marchand L, Donlon T, Kolonel LN, Henderson BE, Wilkens LR: Estrogen metabolism-related genes and breast cancer risk: the multiethnic cohort study. Cancer Epidemiol Biomarkers Prev 2005, 14:1998-2003.

50. Rebbeck TR, Troxel AB, Walker AH, Panossian S, Gallagher S, Shatalova EG, Blanchard R, Norman S, Bunin G, DeMichele A, Berlin M, Schinnar R, Berlin JA, Strom BL: Pairwise combinations of estrogen metabolism genotypes in postmenopausal breast cancer etiology. Cancer Epidemiol Biomarkers Prev 2007, 16:444-450.

51. The MARIE-GENICA Consortium on Genetic Susceptibility for Menopausal Hormone Therapy Related Breast Cancer Risk: Genetic polymorphisms in phase I and phase II enzymes and breast cancer risk associated with menopausal hormone therapy in postmenopausal women. Breast Cancer Res Treat 2010, 119:463-474.

52. Reding KW, Weiss NS, Chen C, Li Cl, Carlson CS, Wilkerson HW, Farin FM, Thummel KE, Daling JR, Malone KE: Genetic polymorphisms in the catechol estrogen metabolism pathway and breast cancer risk. Cancer Epidemiol Biomarkers Prev 2009, 18:1461-1467.

53. Choi JY, Lee KM, Park SK, Noh DY, Ahn SH, Chung HW, Han W, Kim JS, Shin SG, Jang IJ, Yoo KY, Hirvonen A, Kang D: Genetic polymorphisms of SULT1A1 and SULT1E1 and the risk and survival of breast cancer. Cancer Epidemiol Biomarkers Prev 2005, 14:1090-1095.

54. Ji Y, Olson J, Zhang J, Hildebrandt $M$, Wang L, Ingle J, Fredericksen Z, Sellers T, Miller W, Dixon JM, Brauch H, Eichelbaum M, Justenhoven C, Hamann U, Ko Y, Bruning T, Chang-Claude J, Wang-Gohrke S, Schaid D, Weinshilboum R: Breast cancer risk reduction and membrane-bound catechol O-methyltransferase genetic polymorphisms. Cancer Res 2008, 68:5997-6005.

55. Justenhoven C, Hamann U, Schubert F, Zapatka M, Pierl CB, Rabstein S, Selinski S, Mueller T, Ickstadt K, Gilbert M, Ko YD, Baisch C, Pesch B, Harth V, Bolt HM, Vollmert C, Illig T, Eils R, Dippon J, Brauch H: Breast cancer: a candidate gene approach across the estrogen metabolic pathway. Breast Cancer Res Treat 2008, 108:137-149. 
56. Reding KW, Li Cl, Weiss NS, Chen C, Carlson CS, Duggan D, Thummel KE, Daling JR, Malone KE: Genetic variation in the progesterone receptor and metabolism pathways and hormone therapy in relation to breast cancer risk. Am J Epidemiol 2009, 170:1241-1249.

57. Gaudet MM, Chanock S, Lissowska J, Berndt SI, Peplonska B, Brinton LA, Welch R, Yeager M, Bardin-Mikolajczak A, Garcia-Closas M: Comprehensive assessment of genetic variation of catechol-O-methyltransferase and breast cancer risk. Cancer Res 2006, 66:9781-9785.

58. Jansson A, Carlsson J, Olsson A, Storm P, Margolin S, Gunnarsson C, Stenmark-Askmalm M, Lindblom A, Persson B, Stal O: A new polymorphism in the coding region of exon four in HSD17B2 in relation to risk of sporadic and hereditary breast cancer. Breast Cancer Res Treat 2007, 106:57-64.

59. Low YL, Li Y, Humphreys K, Thalamuthu A, Darabi H, Wedren S, Bonnard C, Czene K, lles MM, Heikkinen T, Aittomaki K, Blomqvist C, Nevanlinna $H$, Hall P, Liu ET, Liu J: Multi-variant pathway association analysis reveals the importance of genetic determinants of estrogen metabolism in breast and endometrial cancer susceptibility. PLoS Genet 2010, 6:e1001012.

60. Kalliokoski A, Niemi M: Impact of OATP transporters on pharmacokinetics. Br J Pharmacol 2009, 158:693-705.

61. van der Deure WM, Friesema EC, de Jong FJ, de Rijke YB, de Jong FH, Uitterlinden AG, Breteler MM, Peeters RP, Visser TJ: Organic anion transporter 1B1: an important factor in hepatic thyroid hormone and estrogen transport and metabolism. Endocrinology 2008, 149:4695-4701.

62. Tamai I, Nozawa T, Koshida M, Nezu J, Sai Y, Tsuji A: Functional characterization of human organic anion transporting polypeptide $B$ (OATP-B) in comparison with liver-specific OATP-C. Pharm Res 2001, 18:1262-1269.

63. Gamage N, Barnett A, Hempel N, Duggleby RG, Windmill KF, Martin JL, McManus ME: Human sulfotransferases and their role in chemical metabolism. Toxicol Sci 2006, 90:5-22.

64. Speroff L, Fritz MA: Clinical Gynecologic Endocrinology and Infertility. 7 edition. Philadelphia: Lippincott Williams \& Wilkins; 2005.

65. Tirona RG, Leake BF, Merino G, Kim RB: Polymorphisms in OATP-C: identification of multiple allelic variants associated with altered transport activity among European- and African-Americans. J Biol Chem 2001, 276:35669-35675.

66. Nozawa T, Nakajima M, Tamai I, Noda K, Nezu J, Sai Y, Tsuji A, Yokoi T: Genetic polymorphisms of human organic anion transporters OATP-C (SLC21A6) and OATP-B (SLC21A9): allele frequencies in the Japanese population and functional analysis. J Pharmacol Exp Ther 2002, 302:804-813.

67. Hunter DJ, Kraft P, Jacobs KB, Cox DG, Yeager M, Hankinson SE, Wacholder S, Wang Z, Welch R, Hutchinson A, Wang J, Yu K, Chatterjee N, Orr N, Willett WC, Colditz GA, Ziegler RG, Berg CD, Buys SS, McCarty CA, Feigelson HS, Calle EE, Thun MJ, Hayes RB, Tucker M, Gerhard DS, Fraumeni JF Jr, Hoover RN, Thomas G, Chanock SJ: A genome-wide association study identifies alleles in FGFR2 associated with risk of sporadic postmenopausal breast cancer. Nat Genet 2007, 39:870-874

68. Conneely KN, Boehnke M: So many correlated tests, so little time! Rapid adjustment of $P$ values for multiple correlated tests. Am J Hum Genet 2007, 81:1158-1168.

\section{doi:10.1186/bcr2859}

Cite this article as: Lee et al.: The association of polymorphisms in hormone metabolism pathway genes, menopausal hormone therapy, and breast cancer risk: a nested case-control study in the California Teachers Study cohort. Breast Cancer Research 2011 13:R37.

\section{Submit your next manuscript to BioMed Central and take full advantage of:}

- Convenient online submission

- Thorough peer review

- No space constraints or color figure charges

- Immediate publication on acceptance

- Inclusion in PubMed, CAS, Scopus and Google Scholar

- Research which is freely available for redistribution

Submit your manuscript at www.biomedcentral.com/submit 